\section{Neurophysiological tests in Type 1 (insulin-dependent) and Type 2 (non-insulin-dependent) diabetic patients with subclinical and symptomatic neuropathy}

\section{Dear Sir,}

In their recent article P.H.Hendriksen et al. [1] report similar percentages of abnormal neurophysiological test results in Type 1 (insulin-dependent) and Type 2 (non-insulin-dependent) diabetic patients with subclinical (asymptomatic) neuropathy, suggesting that there are no differences in the manifestation of neuropathy in relation to the type of diabetes.

We have assessed peripheral nerve function using nerve conduction and quantitative sensory tests in 130 Type 1 and 45 Type 2 diabetic patients, classified according to the recommendations of the
National Diabetes Data Group [2], without neuropathic symptoms [age: $28(14-62)$ and $54(40-75)$ years (median, range), duration of diabetes: $10(1-44)$ and $9(1-30)$ years] and in 65 Type 1 and 91 Type 2 diabetic subjects with symptoms of peripheral neuropathy [age: $44(15-69)$ and $63(40-82)$ years, duration of diabetes: $20(2-53)$ and $12(1-50)$ years]. Age-dependent normal ranges for the neurophysiological tests have been established in 57 (nerve conduction) and 70 (thermal, pain, and vibration sensation thresholds) healthy subjects as previously described $[3,4]$.

The percentages of abnormal test results in the four groups studied are shown in Table 1 . In both the asymptomatic and symptomatic Type 2 diabetic patients the thermal discrimination threshold on the hand, pain perception threshold to heat and cold on the foot, metacarpal and malleolar vibration perception threshold, and peroneal motor nerve conduction were significantly more frequently abnormal as compared with the corresponding group of subjects with Type 1 diabetes $(p<0.05)$. In addition, among the patients with symptomatic neuropathy, the group with Type 2 diabetes showed a significantly higher percentage of abnormalitites for the

Table 1. Abnormalities in peripheral nerve function tests in Type 1 (insulin-dependent) and Type 2 (non-insulin-dependent) diabetic patients without or with symptoms of peripheral neuropathy

\begin{tabular}{|c|c|c|c|c|c|}
\hline & & \multicolumn{2}{|c|}{ Patients without neuropathic symptoms } & \multicolumn{2}{|c|}{ Patients with neuropathic symptoms } \\
\hline & & $\begin{array}{l}\text { Type } 1 \text { diabetes } \\
n(\%)\end{array}$ & $\begin{array}{l}\text { Type } 2 \text { diabetes } \\
n(\%)\end{array}$ & $\begin{array}{l}\text { Type } 1 \text { diabetes } \\
n(\%)\end{array}$ & $\begin{array}{l}\text { Type } 2 \text { diabetes } \\
n(\%)\end{array}$ \\
\hline \multicolumn{6}{|c|}{ Thermal discrimination threshold } \\
\hline & $\begin{array}{l}\text { Thenar eminence } \\
\text { Foot }\end{array}$ & $\begin{array}{l}21 / 130(16.2) \\
36 / 129(27.9)\end{array}$ & $\begin{array}{l}16 / 45(35.6)^{\mathrm{a}} \\
18 / 45(40.0)\end{array}$ & $\begin{array}{l}20 / 65(30.8) \\
39 / 65(60.0)\end{array}$ & $\begin{array}{l}59 / 91(64.8)^{a} \\
60 / 91(65.9)\end{array}$ \\
\hline \multicolumn{6}{|c|}{ Pain perception threshold } \\
\hline $\begin{array}{l}\text { Heat: } \\
\text { Cold: }\end{array}$ & $\begin{array}{l}\text { Thenar eminence } \\
\text { Foot } \\
\text { Thenar eminence } \\
\text { Foot }\end{array}$ & $\begin{array}{c}14 / 122(11.5) \\
6 / 122(4.9) \\
28 / 121(23.1) \\
22 / 121(18.2)\end{array}$ & $\begin{array}{c}8 / 40(20.0) \\
10 / 40(25.0)^{\mathrm{a}} \\
14 / 40(35.0) \\
16 / 40(40.0)^{a}\end{array}$ & $\begin{array}{c}8 / 56(14.3) \\
3 / 57(5.3) \\
7 / 56(12.5) \\
17 / 57(29.8)\end{array}$ & $\begin{array}{l}16 / 86(18.6) \\
18 / 84(21.4)^{\mathrm{a}} \\
29 / 86(33.7)^{\mathrm{a}} \\
46 / 85(54.1)^{\mathrm{a}}\end{array}$ \\
\hline \multicolumn{6}{|c|}{ Vibration perception threshold } \\
\hline & $\begin{array}{l}\text { Metacarpal } \\
\text { Malleolar }\end{array}$ & $\begin{array}{l}12 / 117(10.3) \\
25 / 125(20.0)\end{array}$ & $\begin{array}{l}10 / 45(22.2)^{a} \\
22 / 45(48.9)^{a}\end{array}$ & $\begin{array}{l}18 / 63(28.6) \\
28 / 64(43.8)\end{array}$ & $\begin{array}{l}43 / 88(48.9)^{\mathrm{a}} \\
67 / 89(75.3)^{\mathrm{a}}\end{array}$ \\
\hline \multicolumn{6}{|c|}{ Nerve conduction velocity } \\
\hline & $\begin{array}{l}\text { Median motor nerve } \\
\text { Peroneal motor nerve } \\
\text { Median sensory nerve } \\
\text { Sural sensory nerve }\end{array}$ & $\begin{array}{l}34 / 130(26.2) \\
40 / 130(30.8) \\
35 / 128(27.3) \\
54 / 130(41.5)\end{array}$ & $\begin{array}{c}6 / 44(13.6) \\
26 / 44(59.1)^{a} \\
6 / 43(14.0) \\
23 / 44(52.3)\end{array}$ & $\begin{array}{l}25 / 65(38.5) \\
44 / 65(67.7) \\
32 / 64(50.0) \\
42 / 65(64.6)\end{array}$ & $\begin{array}{l}34 / 91(37.4) \\
77 / 91(84.6)^{a} \\
40 / 85(47.1) \\
74 / 90(82.2)^{a}\end{array}$ \\
\hline
\end{tabular}

${ }^{2} p<0.05$ vs Type 1 diabetes 
pain perception threshold to cold stimuli on the hand and sural sensory nerve conduction than the group with Type 1 diabetes $(p<0.05)$.

These results suggest a higher degree of both small and large nerve fibre dysfunction in the upper and lower limbs among Type 2 compared to Type 1 diabetic patients with either subclinical and symptomatic peripheral neuropathy. The most prominent deficits were noted for nerve conduction and thermal discrimination and vibration perception thresholds in the lower limbs, indicating a parallel involvement of small and large nerve fibre dysfunction in both subclinical and symptomatic diabetic neuropathy. One possible explanation for the observed differences could be a histopathological heterogeneity of the distal symmetrical neuropathy, with predominant axo-glial dysjunction in Type 1 diabetes in contrast to focal fibre loss and Wallerian degeneration in Type 2 diabetes [5]. It is conceivable the endoneurial microvascular abnormalities play a reinforcing role in the pathogenesis of neuropathy in Type 2 diabetes. Such distinct morphological findings may reflect a pathogenetic variability in relation to the type of diabetes, which could have been responsible for the quantitative differences observed in our study.

Recently, we have provided further evidence in favour of a more pronounced degree of neuropathy in Type 2 diabetes in a multicentre study of 647 Type 1 and 524 Type 2 diabetic patients by showing a significantly higher prevalence of subclinical autonomic neuropathy in the latter group (16.8 vs $22.1 \%$ ) as assessed by cardiovascular reflex tests [6]. Thus, our findings support the concept of quantitative differences, rather than similarities, in the manifestation of subclinical or symptomatic neuropathy between Type 1 and Type 2 diabetic patients.

Yours sincerely,

D. Ziegler, H. Mühlen and F. A. Gries

\section{References}

1. Hendriksen PH, Oey PL, Wieneke GH, Bravenboer B, Banga JD (1992) Subclinical diabetic neuropathy: similarities between electrophysiological results of patients with type 1 (insulin-dependent) and type 2 (non-insulin-dependent) diabetes mellitus. Diabetologia 35: $690-695$

2. National Diabetes Data Group (1979) Classification and diagnosis of diabetes mellitus and other categories of glucose intolerance. Diabetes 28: 1039-1057

3. Ziegler D, Mayer P, Wiefels K, Gries FA (1988) Assessment of small and large fiber function in long-term type 1 (insulin-dependent) diabetic patients with and without painful neuropathy. Pain 34: 1-10

4. Ziegler D, Mayer P, Mühlen H, Gries FA (1991) The natural history of somatosensory and autonomic nerve dysfunction in relation to glycaemic control during the first 5 years after diagnosis of type 1 (insulin-dependent) diabetes mellitus. Diabetologia 34: $822-829$

5. Sima AAF, Nathaniel V, Bril V, McEwen TAGJ, Greene DA (1988) Histopathological heterogeneity of neuropathy in insulindependent and non-insulin-dependent diabetes and demonstration of axo-glial dysjunction in human diabetic neuropathy. $\mathrm{J}$ Clin Invest $81: 349-364$

6. Ziegler D, Gries FA, Spüler M, Lessmann F, Diabetic Cardiovascular Autonomic Neuropathy Multicenter Study Group (1992) The epidemiology of diabetic neuropathy. J Diab Complications 6: 25-33

Dr.D.Ziegler

Diabetes Research Institute, Heinrich-Heine-University

Auf'm Hennekamp 65, W-4000 Düsseldorf 1, FRG

\section{Errata}

\section{Diabetologia, Volume 35, Number 3, March 1992}

pp 277-282, S. Lo et al.: Altered Islet Beta-cell function before the onset of Type 1 (insulin-dependent) diabetes mellitus.

The absolute insulin levels in nmol/ reported in this paper are incorrect, through an error which is systematic and, therefore, does not alter the conclusions. The error is due to a misleading label on a (WHO) international insulin standard supplied by the National Institute of Biological Standards Control. The vial was labelled as " $5.4699 \mathrm{mg}$ of this preparation when diluted to $1 \mathrm{ml}$ will contain $3 \mathrm{IU}$ insulin activity". It has come to our attention that the weight, in this particular case, refers to the total protein content not the insulin content. The National Institute have been informed of this potential source of error and they have provided us with the insulin content of that standard. The labels on the present standards from the Institute refer to insulin activity per unit weight of insulin. To obtain the correct values for insulin in $\mathrm{nmol} / \mathrm{l}$ or $\mathrm{pmol} / \mathrm{l}$ all insulin levels in the above paper should be multiplied by 0.023766 or 23.766 respectively.

S.S.Lo, M.Hawa, D. A. Pyke and R.D. G.Leslie

\section{Diabetologia, Volune 35, Number 6, June 1992}

pp 499-504, R. Larkins and M.Dunlop: The link between hyperglycaemia and diabetic nephropathy.

Figure 2 of our recent review of the link between hyperglycaemia and diabetic nephropathy [1] conveyed the incorrect impression that the increased NADH: NAD + ratio consequent on increased oxidation of sorbitol to fructose was directly coupled to increased formation of dihydroxyacetone phosphate from glyceraldehyde-3-phosphate. The proposed link is in fact indirect, with the increased
$\mathrm{NADH}: \mathrm{NAD}+$ ratio tending to inhibit glyceraldehyde-3-phosphate dehydrogenase, with its consequent increased diversion of glyceraldehyde-3-phosphate to dihydroxyacetone phosphate and its subsequent conversion to diacylglycerol, either as indicated in Figure 2, or following reduction to glycerol-3-phosphate (which would also be favoured by an increased ratio of NADH:NAD + ) as proposed by Wolf et al. [2].

The proposal that increased aldose reductase pathway activity favours de novo diacylglycerol synthesis as postulated in our review and by Wolf et al. [2] is not altered.

We thank Prof. W.J. Malaisse for drawing this error to our attention.

\section{R. Larkins and M.Dunlop}

1. Larkins RG, Dunlop ME (1992) The link between hyperglycaemia and diabetic nephropathy. Diabetologia 35: 499-504

2. Wolf BA, Williamson JR, Eason RA, Chang K, Sherman WR, Turk J (1991) Diacylglycerol accumulation and microvascular abnormalities induced by elevated glucose levels. J Clin Invest 87 : $31-38$

\section{Diabetologia, Volume 35, Number 8, August 1992}

pp 743-747, S. Nishi et al.: Human pancreatic Beta-cell glucokinase: cDNA sequence and localization of the polymorphic gene to chromosome 7, band $\mathrm{p} 13$.

A error has been made in our sequence of human Beta-cell glucokinase in Figure 1. Amino acid 171 should be Phe (TTC). The correct sequence has been submitted to the GenBank database. The accession number is M88011. We regret any inconvenience caused by this mistake. 